\title{
El model lingüistic educatiu a Catalunya el segle XXI. De l'estabilitat a la resistència
}

\author{
[The Educational Linguistic Model in 21st- Century Catalonia. \\ From Stability to Resistance]
}

\author{
Miquel Àngel Pradilla Cardona \\ Universitat Rovira $i$ Virgili \& Institut d'Estudis Catalans \\ miquelangel.pradilla@urv.cat
}

Resum: La planificació de l'adquisició (acquisition planning) d'una llengua és un dels grans centres d'atenció de les polítiques i planificacions lingüístiques. Més enllà de la creació de nous usuaris, els models lingüístics educatius tenen (o haurien de tenir) un paper rellevant en la modificació de comportaments i actituds envers les llengües del repertori lingüístic. En l'àmbit lingüístic de la llengua catalana, les dinàmiques sociopolítiques que s'hi han viscut des de l'adveniment de la democràcia han propiciat una colllisió d'interessos al voltant de l'horitzó de funcionalitat que es vol atorgar a la llengua històrica i territorial. L'article que el lector té a les mans té com a objectiu detallar l'itinerari involutiu a què s'ha volgut sotmetre el model de conjunció lingüística a la Catalunya del segle XxI.

Paraules clau: Planificació lingüística, planificació de l'adquisició, sociolingüística, ensenyament, ideologia, llengua catalana

AвSTRACT: The acquisition planning of a language is one of the main focuses of linguistic policies and planning. Besides the creation of new users, educational linguistic models play or should play a significant role in the modification of behaviour and attitudes applied towards the set varieties of languages that conform the linguistic repertoire. In the field of the Catalan language, the socio-political dynamics that have occurred since the onset of democracy, have led to a clash of interests with the value of functionality that is commonly ascribed to the the historical and territorial languages. The aim of this article is to elaborate on the regressive itinerary that the model of linguistic conjunction has been subject to in Catalonia during the twenty- first century.

KEYWORDS: Language planning, acquisition planning, sociolinguistics, teaching, ideology, Catalan language

Recepció: 07/O9/20I7. Acceptació: OI/IO/20I7. Publicació: I 5/I2/20I 7

REVISTA VALENCIANA DE FILOLOGIA / I (20I7) p. 223-239/ISSN 0556-705X/ DOI I0.28939/RVF.VIII.28 


\section{Obertura}

La conflictivitat contemporània que està vivint l'àmbit educatiu en bona part del territori catalanòfon ha estat la causa principal que ens ha menat a centrar la nostra atenció en el món de l'ensenyament, en aquesta ocasió a Catalunya. El paraigua teòric que ens ha permès discriminar la planificació funcional de la planificació de l'adquisició ens arriba de la mà de Cooper (1989). Així, mentre que la primera s'ocuparia de la intervenció sobre els usos lingüístics, la segona atendria un vessant no menys important, la creació d'usuaris.

En l'apartat següent centrarem la nostra anàlisi en l'àmbit educatiu català. La nostra hipòtesi de partida preveu que, des del moment que l'ensenyament de la llengua té un paper rellevant en la formulació de polítiques lingüístiques destinades a modificar actituds i comportaments, esdevé un dels focus de tensió més importants del nostre conflicte lingüístic. En aquest sentit, els darrers temps hem assistit a una col-lisió entre posicionaments divergents, ara en relació amb els models que prioritzen que la llengua catalana siga vehicular (Catalunya i Illes Balears), ara pel que fa al model de tria de la llengua del primer ensenyament (País Valencià). La manca de consens en una qüestió tan important per a la definició de l'horitzó de funcionalitat que es vol per a la llengua històrica i territorial és a la base dels canvis de model de gestió del multilingüisme que ha propiciat l'alternança de poder, de manera continuada a les Illes Balears i més recentment al País Valencià.

D'altra banda, abans d'endinsar-nos en l'anàlisi de l'esdevenidor del model educatiu català, no hem de passar per alt un fet d'una importància cabdal. Ens referim a la gestió asimètrica del multilingüisme que s'impulsa des de l'Estat. Si ens cenyim únicament al segle xxi, l'Estat espanyol ha vist passar pel Govern central els dos grans partits d'àmbit estatal. Així, després de dues legislatures de govern del PP (1996-2004), entre els anys 2004-2011 l'esquerra va ocupar el poder de la mà del PSOE, i a partir del novembre de 2011 el va substituir novament el PP. L'esmentada alternança estableix dues etapes en què el món educatiu s'haurà d'adaptar a programes ideològics clarament distanciats. Ara bé, en relació amb la gestió del multilingüisme estatal, totes

REVISTA VALENCIANA DE FILOLOGIA / I (20I7) p. 223-239

MIQUEL ÀNGEL PRADILLA CARDONA

El model lingüístic educatiu a Catalunya el segle XXI / 224 
dues formacions polítiques entenen el respecte i el reconeixement de la diversitat lingüística estatal des d'un plantejament jeràrquic que privilegia la llengua castellana. I si bé és obvi que el discurs desacomplexadament uniformitzador de la dreta no és compartit per (una part de) l'esquerra, a la pràctica, això és, en els moments en què aquesta ha administrat el poder, no ha actuat amb determinació per tal de resoldre qüestions actitudinals d'importància vital. La difusió d'ideologies lingüístiques que positivitzen el mosaic lingüístic estatal i el patrimonialitzen entre una població a hores d'ara encara instruïda en una visió clarament distorsionada del que hauria de ser un marc lingüístic de convivència continua sent un repte colossal. Lluny d'això, el discurs supremacista de la «lengua común» sol aparèixer cíclicament, des de la transversalitat ideològica d'unes determinades elits culturals espanyoles, amb l'aquiescència més o menys (in)dissimulada del poder de torn. Un cas paradigmàtic d'aquest procedir el trobem en la difusió del Manifiesto por una lengua común, pamflet presentat el 23 de juny de 2008, que defensa l'asimetria entre les llengües oficials a favor de l'espanyol i, en última instància, qüestiona a les llengües minoritzades de l'Estat el dret de promoure polítiques intervencionistes en el marc de processos de normalització lingüística.

Si ens remuntem als inicis del nou mil·lenni, ens adonarem que el sistema educatiu espanyol s'ha hagut d'adaptar a tres lleis orgàniques: la Llei orgànica 10/2002, del 23 de desembre, de qualitat de l'educació (LOCE), aprovada per la majoria absoluta del Govern del PP; la Llei orgànica 2/2006, del 3 de maig, d'educació (LOE), aprovada pel Govern del PSOE, i la Llei orgànica 8/2013, del 9 de desembre, per a la millora de la qualitat educativa (LOMCE), promoguda per un PP novament al poder i decidit a torpedinar per la via legislativa estatal els models educatius autonòmics que privilegien les llengües històriques i territorials. Atès que les polítiques educatives de Catalunya, les Illes Balears, el País Valencià i la Franja s'aixopluguen en les esmentades lleis d'àmbit estatal, no ens ha d'estranyar que s'hagen produit col-lisions importants. D'altra banda, no cal ser un analista gaire fi per concloure que el gran objectiu de la nova regulació és impugnar el model lingüístic educatiu català, sens dubte el més compromès en la rehabilitació de la llengua pròpia.

REVISTA VALENCIANA DE FILOLOGIA / I (20I7) p. 223-239

MIQUEL ÀNGEL PRADILLA CARDONA

El model lingüistic educatiu a Catalunya el segle XXI / 225 


\section{Nucli}

Des de l'any 1978, en el marc històric d'una transició no exempta de conflictivat en l'àmbit lingüistic i educatiu, el pes de la llengua catalana a l'ensenyament ha anat augmentant. Paral-lelament, la judicialització de l'incipient model lingüistic educatiu català també ha assolit un cert grau d'estabilitat. ${ }^{1}$ Així, la Llei de política lingüística de 1998 consolidarà el model de conjunció lingüística a Catalunya. El català hi serà considerat llengua pròpia d'ús normal en l'ensenyament (art. 20) i llengua vehicular i d'aprenentatge. Alhora, establirà que les dues llengües oficials han de tenir una presència adequada en els plans d'estudi per tal d'assegurar-ne el domini formal de l'alumnat al final de l'educació obligatòria (art. 21).

Amb la llengua catalana com a centre de gravetat del sistema educatiu català, s'encara un tombant de mil-lenni que aportarà novetats glotopolítiques destacables. La més important serà l'inici, l'any 2000, d'una segona legislatura del PP al poder estatal. La majoria absoluta obtinguda pel Govern conservador dóna pas a una política centralitzadora, que aposta desacomplexadament per una visió castellanocèntrica del món lingüisticocultural. Una política que identifica el món educatiu com un espai d'intervenció estratègica per tal de consolidar la seua aposta identitària. Amb aquesta finalitat s'aniran succeint tot un seguit d'accions, com la creació d'un districte universitari únic, la Llei orgànica d'universitats (LOU) i la Llei orgànica de qualitat de l'educació (LOCE).

La nova etapa, que ens projectarà a la contemporaneïtat més immediata, començarà, doncs, amb la continuïtat de José María Aznar al poder estatal. Un governant, no ho oblidem, que, si bé en la legislatura anterior afirmava «parlar

1 Una mostra fefaent la tenim en el recurs d'inconstitucionalitat contra determinats articles de la Llei de normalització lingüística de 1983, interposat el 15 de febrer de 1994 al Tribunal Constitucional per la Sala Tercera del Tribunal Suprem. La forta sacsejada que va provocar l'esmentat recurs va suscitar un nou debat entre partidaris i detractors del model lingüístic català, un debat que va cloure, si més no provisionalment, la sentència del Tribunal Constitucional 337/1994, del 23 de desembre de 1994. Aquesta sentència esdevindrà una fita destacada en el blindatge legal del model de conjunció lingüística, ja que legitima l'autoritat de la Generalitat de Catalunya en matèria educativa i no qüestiona el model que ha elegit per tal de garantir el coneixement de català i castellà.

REVISTA VALENCIANA DE FILOLOGIA / I (20I7) p. 223-239

MIQUEL ÀNGEL PRADILLA CARDONA

El model lingüístic educatiu a Catalunya el segle XXI / 226 
català en la intimitat» —quan requeria el suport de CiU a l'hora de garantir la seua presència al Govern de l'Estat-, amb la nova aritmètica parlamentària impulsarà un gir substancial en relació amb la dinàmica centre-perifèria. Una dinàmica, en definitiva, molt més hostil cap a la diversitat lingüística i nacional d'un Estat espanyol que s'entendrà com un ens monolític. Malgrat el parèntesi de vuit anys que va representar la gestió del poder estatal pel PSOE (20042011), considerem que les bases programàtiques d'aquesta actitud més intolerant cap a les anomenades llengües autonòmiques es van començar a gestar durant l'esmentada legislatura. Una actitud que s'ha reprès, amb una virulència inusitada, amb la tornada al poder del partit conservador el 2011.

Sens dubte, la Llei orgànica 10/2002, del 23 de desembre, de qualitat de l'educació (LOCE), ha de centrar la nostra atenció en aquest període. I ho farem, més que per l'impacte que va tenir al seu moment — limitat a causa de la seua derogació pocs anys després-, per la nova doctrina involucionista que proclamava. La LOCE substituirà la Llei orgànica d'ordenació general del sistema educatiu (LOGSE) de 1990, una llei que, malgrat no deslliurar-se de l'esperit uniformista, permetia la incorporació de currículums específics per a les llengües altres que el castellà i, qüestió fonamental, no predeterminava la llengua vehicular de l'ensenyament. La nova llei partia d'una no explicitació gens trivial del respecte i la protecció constitucionals de què ha de ser objecte la diversitat lingüística estatal. Aquesta absència tan significativa es troba en plena sintonia amb la promulgació de tot un seguit de reials decrets (Reial decret 831/2003 i Reial decret 832/2003, tots dos del 27 de juny) que encotillaran considerablement la capacitat de les comunitats autònomes per a dissenyar i regular polítiques educatives pròpies. No cal dir que el debat que va suscitar la nova llei, abans i després de la seua publicació, va ser molt intens. El desacord era tan profund que la Generalitat de Catalunya va impugnar els decrets esmentats, ja que la seua aplicació posava en qüestió el model lingüístic vigent.

Malgrat tot, la posició de la llengua catalana en el model lingüístic escolar no es va veure alterada significativament. Si de cas, destacarem una sentència del setembre de 2004 segons la qual el Tribunal Superior de Justícia de Catalunya (TSJC), atenent un recurs presentat per l'eurodiputat del PP Alejo

REVISTA VALENCIANA DE FILOLOGIA / I (20I7) p. 223-239 MIQUEL ÀNGEL PRADILLA CARDONA El model lingüistic educatiu a Catalunya el segle XXI / 227 
Vidal-Quadras i l'associació Convivencia Cívica Catalana, es pronunciarà sobre el dret de l'alumnat a triar la llengua del primer ensenyament. En aquest sentit considera que caldria explicitar-lo en l'imprès de preinscripció. La mateixa qüestió serà represa un any més tard per una nova sentència, del 5 de desembre de 2005, la qual adverteix la Generalitat de Catalunya de la necessitat d'incorporar una casella en els formularis d'inscripció escolar que indiqués l'opció de la llengua castellana en el cicle inicial d'educació primària. En el rerefons hi ha el qüestionament de l'atenció i el suport material individualitzats per als qui ho sol-liciten.

En l'àmbit de la política autonòmica, les eleccions del 16 de novembre de 2003 van propiciar l'accés al Govern català d'una gran coalició d'esquerres formada pel PSC, ERC i ICV - Esquerra Unida i Alternativa (EUiA). El 14 de desembre se signarà el Pacte del Tinell (Acord per a un govern catalanista $i$ d'esquerres a la Generalitat de Catalunya) i l'anomenat Govern tripartit obrirà una nova etapa, tot desplaçant una CiU que havia monopolitzat el poder els vint-i-tres anys anteriors. L'esquerra al poder autonòmic veurà reforçat el seu paper un any més tard, quan l'aritmètica parlamentària resultant de les eleccions estatals de 2004 farà imprescindible el suport català per a l'accés de José Luis Rodríguez Zapatero al Govern central. Amb aquesta nova conjuntura, tot i les escaramusses cròniques derivades del litigi en què viu instal·lat el món educatiu català, es podria afirmar que el període en qüestió va estar presidit per una certa estabilitat. Això va permetre que una part substancial del debat es desplacés cap a una nova realitat que demanava desesperadament un nou model de gestió. Ens estem referint al nou ecosistema comunicatiu que havien conformat unes migracions massives i que ens situava de ple en un horitzó multilingüe al qual l'escola havia de donar resposta.

La integració lingüística de l'important contingent de població immigrant es revelarà, doncs, com un repte indefugible. Un objectiu, però, que només esdevé un dels vèrtexs d'una incorporació a la societat d'acollida que també hauria de ser reeixida des dels punts de vista social i laboral. De fet, les polítiques d'igualtat i d'acomodació de la ciutadania, la nova i l'autòctona, haurien de constituir-se en veritables polítiques lingüístiques. Només un plantejament in-

REVISTA VALENCIANA DE FILOLOGIA / I (20I7) p. 223-239

MIQUEL ÀNGEL PRADILLA CARDONA

El model lingüistic educatiu a Catalunya el segle XXI / 228 
tegral podia abordar la difícil comesa de cohesionar una societat culturalment i socialment diversa. Amb aquest horitzó, el Govern català acumula una important tradició de polítiques d'immigració. Un precedent important el constitueix la creació, el 1992, de la Comissió Interdepartamental per al Seguiment i la Coordinació de les Actuacions en Matèria d'Immigració. Aquest òrgan va ser l'encarregat d'elaborar el I Pla Interdepartamental d'Immigració (1993-2000). La creació de la Secretaria per a la Immigració l'agost de 2000 va representar un nou pas endavant que va tenir com a conseqüència immediata l'elaboració del II Pla Interdepartamental d'Immigració (2000-2004). El marc polític d'actuació s'aixoplugava en el Pla de Ciutadania i Immigració 2005-2008. ${ }^{2}$ La seua formulació s'articulava al voltant de dotze punts, dels quals, per a l'avinentesa que ens ocupa, en destacarem un parell: el 4, que fa referència al desenvolupament de polítiques educatives interculturals per a la cohesió social, i el 6, que planteja l'impuls del coneixement i l'ús del català. Tots dos punts coincideixen a presentar el sistema educatiu com un espai d'ús de la llengua catalana, la qual ha d'assumir el rol d'element comú d'identitat i de cohesió.

Durant el període al poder del Govern tripartit, la política lingüística destinada a afavorir l'arrelament lingüístic en català de la població immigrada presentarà un esquema de transversalitat departamental, amb diversos fronts d'actuació. El paper de l'escola, per la seua centralitat, serà determinant. Però també voldríem destacar un parell d'experiències de gran interès: una d'institucional en l'àmbit municipal i una altra de cívica, el programa Voluntariat per la llengua. La primera va impulsar plans d'acollida lingüística a poblacions de perfils diversos (Badalona, Banyoles, Lleida, Manlleu, Reus, Ulldecona i Vic). Es tracta de programes pilot per a l'impuls del coneixement i l'ús de la llengua catalana en un marc de coordinació del conjunt d'organismes i entitats que participen en l'acolliment de les persones nouvingudes. Els resultats d'aquests plans pilot havien de proporcionar unes bases sòlides per a l'extensió progressiva de l'experiència a altres localitats. D'altra banda, el programa Voluntariat

2 Es pot consultar a <http://benestar.gencat.cat/web/.content/03ambits_tematics/05immigracio/03politiquesplansactuacio/antecedents/memoria_pla.pdf>.

REVISTA VALENCIANA DE FILOLOGIA / I (20I7) p. 223-239

MIQUEL ÀNGEL PRADILLA CARDONA

El model lingüistic educatiu a Catalunya el segle XXI / 229 
per la llengua s'ha erigit com una de les experiències més reeixides d'acolliment lingüístic, fins al punt que ha rebut un reconeixement explícit de la Comissió Europea com una de les millors experiències pedagògiques d'aprenentatge de la Unió Europea. Impulsat des de diversos departaments de la Generalitat, aquest programa ha comptat amb la col-laboració de més de dues-centes entitats de la societat civil. Val a dir que el programa depassa amb escreix l'objectiu primigeni de proporcionar espais d'ús de la llengua que millorin l'expressió oral dels nouvinguts. L'experiència també propicia l'establiment de lligams emocionals amb els autòctons, els quals veuen reforçat el seu paper protagonista en la imprescindible visualització de la presència social de la llengua catalana.

En el marc dels períodes legislatius suara esmentats, hi ha un parell de qüestions que ocuparan un lloc rellevant. Totes dues es formalitzaran l'any 2006. La primera, d'àmbit estatal, comportarà la promulgació de la Llei orgànica 2/2006, del 3 de maig, d'educació (LOE). La segona, d'especial transcendència per a l'àmbit autonòmic, l'aprovació del nou Estatut català.

En relació amb la legislació educativa espanyola, una de les diferències fonamentals entre la LOCE i la LOE l'hem de cercar en l'impacte sobre els models lingüístics escolars dels «ensenyaments comuns» impulsats per la LOCE (art. 8.2) i els «ensenyaments de mínims» (art. 6) que patrocina la LOE. En aquest sentit, si més no programàticament, la LOE presentarà una versió més amable d'una legislació espanyola que manté, però, una vocació uniformista difícilment conciliable amb les aspiracions del sistema educatiu català. No en va, a finals de 2006 un nou reial decret obligava a introduir una tercera hora de castellà en el currículum de primària. La polèmica de la tercera hora va constituir un torpede en plena línia de flotació d'un Govern tripartit que va veure perillar seriosament la seua estabilitat interna. Un debat intern que es va superar amb la impugnació del Reial decret i, alhora, la flexibilització de la seua aplicació mitjançant el desplaçament de l'increment d'hores de llengua castellana al darrer cicle de primària (10-12 anys).

Quant al nou Estatut, allò fonamental que cal destacar en l'àmbit educatiu és que consolida el model de conjunció lingüística en el marc d'un reforçament legislatiu generalitzat de la posició de la llengua catalana a Catalunya.

REVISTA VALENCIANA DE FILOLOGIA / I (20I7) p. 223-239 MIQUEL ÀNGEL PRADILLA CARDONA El model lingüístic educatiu a Catalunya el segle XXI / 230 
Una posició que és qüestionada radicalment pels sectors sociopolítics habituals, els quals interposaran recursos d'inconstitucionalitat sobre les prerrogatives lingüístiques que regulen l'ensenyament, entre altres qüestions. La judicialització de l'ordenament lingüístic català, amb una atenció especial al model lingüístic escolar, prendrà una nova volada. D'altra banda, el PP, en la campanya prèvia a les eleccions generals del 9 de març de 2008, iniciarà una ofensiva ideològica d'alta intensitat amb la cantarella insidiosa de la discriminació del castellà en les aules públiques catalanes. En aquesta croada anirà de bracet d'altres partits, com Ciutadans i Unión, Progreso y Democracia (UPyD), contraris a la política lingüística educativa del Govern tripartit.

Mentrestant, una nova llei que hauria de regular el món educatiu català anava fent camí. Així, després d'intensos debats, veu la llum la Llei 12/2009, del 10 de juliol, d'educació de Catalunya (LEC). Ho farà amb el suport d'un 80 \% dels vots, de la mà de PSC, ERC i CiU. Hi votaran en contra, encara que per raons diferents, PP i Ciutadans, d'una banda, i ICV-EUiA, de l'altra. L'aprovació de la Llei comportarà la represa virulenta dels debats que la van precedir. La reacció dels dos grans partits d'àmbit estatal va ser diferent: mentre que el PSOE, al Govern de l'Estat, no en va fer qüestió, el 6 de desembre el PP va presentar un recurs d'inconstitucionalitat. I, atès que la LEC descansa en la nova doctrina que emana de l'EAC, comença a prendre força la percepció que una sentència negativa del Tribunal Constitucional al conjunt de recursos interposats podria alterar substancialment un model lingüístic que, tot i els entrebancs legals que ha patit, s'havia anat aplicant sense gaires alteracions.

I finalment arriba la temuda sentència del Tribunal Constitucional 31/2010, del 28 de juny, sobre l'Estatut, que en l'àmbit educatiu obre les portes a un nou plantejament que no excloga que la llengua castellana siga vehicular. D'aquesta manera, la judicatura impugna una doctrina amb una llarga trajectòria jurídica al darrere, que preveia l'ús del català com a llengua normal d'ús vehicular i d'aprenentatge en el sistema educatiu català.

Arribats en aquest punt, voldríem fer notar que el caràcter polític del pronunciament queda palès en l'absència de consideracions pedagògiques, un aspecte que hauria d'haver presidit en tot moment una presa de posició tan

REVISTA VALENCIANA DE FILOLOGIA / I (20I7) p. 223-239 MIQUEL ÀNGEL PRADILLA CARDONA

El model lingüistic educatiu a Catalunya el segle XXI / 23 I 
important. En aquest sentit, ens agradaria destacar que els informes a l'abast determinen un coneixement parell d'ambdues llengües oficials entre un alumnat que, alhora, acredita uns coneixements de castellà equiparables als de la mitjana estatal. ${ }^{3} \mathrm{D}$ 'altra banda, també voldríem posar èmfasi en l'alta consideració internacional que el model d'immersió lingüística ha suscitat com a model de cohesió social i d'igualtat d'oportunitats. Sense anar més lluny, recomanem al lector interessat la lectura de l'Informe del Comitè d'Experts del desembre de 2008 i les recomanacions del Comitè de Ministres del Consell d'Europa sobre l'aplicació a l'Estat espanyol de la CELRM. En els esmentats textos s'hi pot trobar una valoració molt positiva del model català i una relació d'incompliments de la Carta Europea per part de l'Estat.

A partir de la sentència del Tribunal Constitucional, s'aniran succeint tot un seguit de notícies legislatives que ens situaran en un estadi de setge judicial sense precedents. Així, al desembre de 2010 veuran la llum tres sentències dictades pel Tribunal Suprem que insisteixen en la llengua castellana com a vehicular. Com ja hem comentat amb anterioritat, la jurisprudència que anirà teixint la interpretació de la sentència de 2010 serà determinant en la viabilitat del sistema educatiu català. No cal dir que les referides sentències del Suprem ja recolzen en la nova doctrina del Constitucional. Alhora, com a conseqüència de les eleccions autonòmiques del 20 de novembre de 2011, el PP recupera el Govern de l'Estat, fet que propicia un entorn polític gens favorable a impulsar reformes legislatives que pal-lien la trencadissa ocasionada en matèria lingüística per la sentència fatídica de 2010.

Una mostra fefaent d'aquest nou tarannà legislador la tenim en la interlocutòria del TSJC del 28 de juliol de 2011 en què s'establirà un termini màxim de

3 Hom pot consultar el document Avaluació de sisè de primària 2010, fet públic pel Consell Superior d'Avaluació del Sistema Educatiu de la Generalitat de Catalunya. S'hi trobarà una síntesi de resultats de la segona prova externa i censal feta a l'alumnat de 6è de primària. A l'Informe sobre la situació de la llengua catalana (2010) (Mayans i Tort, 2011b, p. 65-66) es precisa que "Malgrat que la mitjana sigui superior en català [73,7 enfront d'un 71,2 en castellà], s'obté un millor resultat en castellà en comprensió lectora (77,9 del castellà enfront d'un 77,1 en català). En canvi l'expressió escrita és superior en català $(68,9$ del català enfront d'un 63,5 en castellà)».

REVISTA VALENCIANA DE FILOLOGIA / I (20I7) p. 223-239

MIQUEL ÀNGEL PRADILLA CARDONA

El model lingüistic educatiu a Catalunya el segle XXI / 232 
dos mesos perquè la Generalitat de Catalunya adapte la llengua castellana com a vehicular al model lingüístic català vigent. Un termini que va quedar en suspens, tot siga dit de passada, com a conseqüència de la interposició per part de la Generalitat d'un recurs de reposició. Tanmateix, el 8 de març de 2012 es dicta una nova interlocutòria en el mateix sentit. En aquest cas, el Tribunal Suprem la ratificarà el 19 de febrer de 2013 i, tot i donar raó a la Generalitat en una qüestió gens trivial com és la de reduir l'afectació als fills dels recurrents, introdueix un nou matís, també gens menystenible: l'execució de la garantia demanada s'ha de fer, en la proporció que la Generalitat considere convenient, «junto con sus condiscípulos». L'afectació, doncs, s'eixampla a l'aula sencera. La polèmica estava servida.

El 2013 les sentències s'aniran succeint sempre en el mateix sentit. I, alhora, la pressió judicial es complementarà amb interlocutòries que vetlen per l'aplicació en els termes proposats dels procediments endegats amb sentència ferma. Paral-lelament, amb un ampli suport del sector educatiu (Somescola.cat) i de l'espectre polític (CiU, ERC, PSC, ICV-EUiA i Candidatura d'Unitat Popular -CUP-), la Generalitat iniciarà una batalla jurídica adduint la invasió de competències i la conculcació de preceptes de la LEC i de l'EAC. Un litigi, convé no oblidar-ho, on els contendents en la disputa compten amb forces molt desequilibrades.

La imposició de mesures cautelars acompanyant les interlocutòries, un procedir absolutament excepcional fins al moment, delata la determinació de la judicatura en l'aplicació de la nova doctrina constitucional. Aquest fet ha obligat el Departament d'Ensenyament de la Generalitat de Catalunya a fer una adaptació de l'atenció lingüística individual prevista en l'article 11.4 de la LEC durant el curs 2013-2014. Segons dades de l'Informe sobre la situació de la llengua catalana (2013) (Mayans, Tort i Areny, 2014: 100-102), a l'octubre de 2013 en tres dels procediments amb sentència ferma, que s'estaven executant sense cap oposició del Tribunal des de maig de 2012, i en dos procediments amb mesures cautelars, s'han dictat interlocutòries que qüestionen el procedir del Departament d'Ensenyament —l'adaptació de l'atenció lingüística abans esmentada-i el requereix a explicitar «las materias que se impartirán en castellano a dichos alumnos junto con los demás compañeros de clase». La novetat

REVISTA VALENCIANA DE FILOLOGIA / I (20I7) p. 223-239 MIQUEL ÀNGEL PRADILLA CARDONA El model lingüistic educatiu a Catalunya el segle XXI / 233 
d'aquestes resolucions és l'amenaça d'intervenció judicial en cas de desobediència en els termes que segueixen: «en caso de que no se fijara esa proporción, o fuera manifiestamente insuficiente para entender que el castellano es también lengua vehicular docente, la Sala procederá a su determinación».

Per si això no fos prou, el període que abraça la nostra anàlisi encara incorporarà un nou focus de tensió. Ens referim a l'aprovació de la Llei orgànica 8/2013, del 9 de desembre, per a la millora de la qualitat educativa (LOMCE), coneguda popularment per la Llei Wert, el ministre que l'ha impulsada. Aquesta llei, emparant-se en una interpretació extraordinàriament restrictiva de la sentència del TC de 2010, no amaga la voluntat de posar definitivament contra les cordes els fonaments del model de conjunció lingüística escolar, veritable punta de llança del procés de normalització lingüística a Catalunya.

En relació amb la llengua castellana n'estableix l'obligatorietat de la seua presència vehicular, juntament amb la de les llengües cooficials. I explicita en l'article 1.99 que «l'Administració educativa ha de garantir una oferta docent sostinguda amb fons públics en què el castellà sigui utilitzat com a llengua vehicular en una proporció raonable». A més, mitjançant disposicions addicionals adverteix que «Si la programació anual de l'Administració educativa competent no garantís oferta docent raonable sostinguda amb fons públics en què el castellà sigui utilitzat com a llengua vehicular, el Ministeri d'Educació, Cultura i Esport, prèvia comprovació d'aquesta situació, assumirà íntegrament, per compte de l'Administració educativa corresponent, les despeses efectives d'escolarització d'aquests alumnes en centres privats en què hi hagi l'oferta amb les condicions i el procediment que es determini reglamentàriament, despeses que repercutirà en aquesta Administració educativa [...] L'obligació financera del Ministeri d'Educació, Cultura i Esport tindrà caràcter excepcional i s'extingirà amb l'adopció per part de l'Administració educativa competent de mesures adequades per garantir els drets lingüístics individuals dels alumnes. A aquests efectes, no es consideraran adequades les mesures que suposin l'atenció individualitzada en castellà o la separació en grups per raó de la llengua habitual». La quantificació de la despesa que hauria d'assumir l'Administració catalana es calcula en $6.000 €$ per alumne.

REVISTA VALENCIANA DE FILOLOGIA / I (20I7) p. 223-239 MIQUEL ÀNGEL PRADILLA CARDONA El model lingüistic educatiu a Catalunya el segle XXI / 234 
No cal dir que si s'arribés a consolidar l'aplicació d'aquesta nova doctrina, l'actual sistema educatiu a Catalunya s'haurà de reformular sota premisses conceptuals ben allunyades de les que han estat vigents fins ara. De moment, el grau d'afectació encara és minso. I la Generalitat de Catalunya, amb la intenció de guanyar temps per tal que una nova conjuntura política en determine la revocació - no oblidem que la Llei en qüestió ha concitat la reprovació de bona part de l'arc parlamentari estatal—, està forçant la nova legalitat amb actuacions internes que pal-lien els efectes del nou context sociolingüístic escolar que es vol instaurar. Caldrà estar atents, doncs, als resultats del setge judicial a què els darrers esdeveniments legislatius ens han abocat.

\section{Coda}

A l'espera de la resolució del Tribunal Constitucional sobre el recurs d'inconstitucionalitat interposat l'octubre de 2009 pel Partit Popular contra la Llei d'educació, hem de saber que el règim lingüístic del sistema educatiu català encaixa plenament amb la doctrina del Tribunal Constitucional, que l'ha avalat en diverses sentències. Especialment rellevants han estat les sentències 337/1994 i 31/2010, les quals garanteixen que els grans eixos del model siguen plenament vigents:

a) Els alumnes no poden ser separats en centres ni en grups de classe diferents per raó de llur llengua habitual (article 11.3 LE).

b) En finalitzar l'ensenyament obligatori els estudiants han de poder tenir el ple domini de les llengües catalana i castellana, d'acord amb el Marc europeu comú de referència per a l'aprenentatge, l'ensenyament i l'avaluació de les llengües (article 10.1 LE).

c) El català és la llengua normalment emprada com a llengua vehicular i d'aprenentatge del sistema educatiu (article 11.1 LEC). Les dues sentències del Tribunal Constitucional manifesten expressament que «resulta perfectamente legítimo que el catalán, en atención al

REVISTA VALENCIANA DE FILOLOGIA / I (2OI7) p. 223-239 MIQUEL ÀNGEL PRADILLA CARDONA El model lingüistic educatiu a Catalunya el segle XXI / 235 
objectivo de la normalización lingüística en Catalunya, sea el centro de gravedad de este modelo de bilingüismo, aunque siempre con el límite de que ello no determine la exclusión del castellano como lengua docente de forma que quede garantizado su conocimiento y uso en el territorio de la Comunidad Autónoma».

d) S'estableixen mesures d'acolliment i d'atenció lingüística i d'adaptació al sistema per als estudiants que s'hi incorporen sense conèixer una de les llengües oficials (article 10.2 LEC).

e) Les mares, els pares o els tutors dels estudiants la llengua habitual dels quals sigui el castellà poden exercir un dret d'opció lingüística en el curs en el qual iniciïn el primer ensenyament, per tal que llur fills rebin atenció lingüística individualitzada en aquesta llengua (article 11.4 LEC).

De moment, el règim lingüístic del sistema educatiu roman impermeable a les sentències del Tribunal Suprem i del Tribunal Superior de Justícia de Catalunya, ja que només afecten els casos particulars i de cap manera al funcionament de tot el sistema.

El 2013 el Tribunal Suprem va anar més enllà i va fer extensives a l'alumnat del grup-classe les mesures que cal adoptar per tal de donar compliment a les sentències favorables als fills dels demandants particulars que reclamaven que el castellà fos vehicular. La Generalitat de Catalunya ha respost amb tots els recursos que l'ordenament jurídic li permet. La seua defensa descansa en la vigència constitucional de la Llei d'educació i l'autonomia dels centres en l'elaboració i l'execució dels seus projectes lingüístics. La impugnació de l'atenció lingüística individualitzada per part del Tribunal Suprem és, si més no, xocant, atesa la legitimació constitucional de què fins ara ha gaudit. Tanmateix, la batalla jurídica encetada no paralitza l'execució de les sentències, de manera que en un conjunt de casos l'Administració educativa catalana ha hagut d'adoptar, davant les mesures cautelars imposades, mesures personalitzades. Des del 2005, segons dades de l'Informe sobre la situació de la llengua catalana (2014), s'han incoat vint-i-cinc procediments judicials, en què els demandants reclamen

REVISTA VALENCIANA DE FILOLOGIA / I (20I7) p. 223-239

MIQUEL ÀNGEL PRADILLA CARDONA

El model lingüístic educatiu a Catalunya el segle XXI / 236 
a la Generalitat de Catalunya que la llengua castellana siga vehicular en una proporció del $50 \%$.

L'altre gran focus de la batalla jurídica es produeix amb la promulgació el setembre de 2013 de la LOMCE. El Govern de la Generalitat entén que la nova regulació educativa impulsada pel ministre Wert envaeix competències de la Generalitat en matèria d'educació (article 131 de l'Estatut) i de llengua pròpia (articles 35 i 143 de l'Estatut), fet pel qual ha interposat recurs d'inconstitucionalitat. La nova llei porta de bracet el Reial Decret 591/2014, d'11 de juliol, que regula el procediment administratiu sobre el reconeixement de la compensació dels costos d'escolarització establerts a l'apartat 4 de la disposició addicional 38 de la LOE. Novament, la Generalitat ha interposat un conflicte positiu de competència davant del Tribunal Constitucional, ja que vulnera les competències de la Generalitat en matèria educativa i, a més, és contrari als drets lingüístics en l'àmbit de l'ensenyament regulats a l'article 35 de l'Estatut i a l'autonomia financera de la Generalitat, establerta als articles 156 de la Constitució i 202 de l'Estatut (Informe sobre la situació de la llengua catalana (2015)).

Els darrers deu anys, l'Administració educativa catalana ha rebut un miler de sol-licituds reclamant, entre d'altres coses, un ensenyament bilingüe. Val a dir que, els darrers anys s'ha detectat un augment de sol-licituds associat amb l'impuls logístic d'associacions com Convivencia Cívica Catalana i, en menor mesura, Asamblea por una Escuela Bilingüe. Concretament, l'any 2013 els reclamants van ser 32 famílies (48 alumnes) i el 2014, 325 (472 alumnes). A hores d'ara, com s'ha dit, l'afectació sistèmica de la demanda constatada és relativament poc important. Tanmateix, tot fa pensar que de la mà d'un setge judicial sense precedents, el conflicte pot agafar noves dimensions.

REVISTA VALENCIANA DE FILOLOGIA / I (20I7) p. 223-239

MIQUEL ÀNGEL PRADILLA CARDONA

El model lingüistic educatiu a Catalunya el segle XXI / 237 


\section{Bibliografia}

Arnau, J. (2002) Llengües i educació a Catalunya: mirada al present i perspectives de futur, Barcelona, Universitat de Barcelona.

Arnau, J.; Artigal, J. M. (1995) «El programa d'immersió a Catalunya», dins J. M. Artigal (ed.) Els programes d'immersió als territoris de llengua catalana, Barcelona, Fundació Jaume Bofill, p. 21-47.

Arnau, J.; BoAdA, H. (1975) «Datos para un conocimiento del bilingüismo escolar en el municipio de Barcelona», dins Bilingüismo y educación en Cataluña, Barcelona, Teide (Publicaciones del Instituto de Ciencias de la Educación, Universidad de Barcelona), p. $19-45$.

Artigal, J. M. (ed.) (1995) Els programes d'immersió als territoris de llengua catalana, Barcelona, Fundació Jaume Bofill.

Cooper, R. L. (1989). Language planning and social change, Cambridge, Cambridge University Press.

Corbeil, J. C. (1980) L'aménagement linguistique du Québec, Mont-real, Guérin.

Mayans, P.; Tort, T. (2011) «Ensenyament», dins M. À. Pradilla; N. Sorolla (coord.) (2011). Informe sobre la situació de la llengua catalana (2010), Barcelona, Observatori de la Llengua Catalana. També disponible en línia a: <http://www.demolinguistica.cat/arxiu/ web/informe/informe2010.pdf> [Consulta: 20 octubre 2014].

Mayans, P.; Tort, T.; Areny, M. (2015) «Ensenyament», dins M. À. Pradilla; N. Sorolla (coord.) (2015) Informe sobre la situació de la llengua catalana (2014), Barcelona, Observatori de la Llengua Catalana.

Mollà, T. (2007a) Quina política lingüística?, Alzira, Bromera.

- (2007b) «Els nous factors de la política lingüística», dins J. ForCADELL; F. Isabel (ed.), A Alacant, en valencià: Observatori de la llengua (2003/2005), Alacant, Universitat d'Alacant, p. 27-46.

-(2001) Ideologia i conflicte lingüístic, Alzira, Bromera.

Pla General de Normalització Lingüística (1995) Barcelona, Generalitat de Catalunya.

Pons, E. (2006) «El estatuto jurídico de las lenguas en Cataluña», dins J. M. Pérez (coord.), Estudios sobre el estatuto jurídico de las lenguas en España, Barcelona, Atelier, p. 281321.

Pradilla, M. À. (2012) «Coneixements, usos i representacions socials de la llengua catalana el 2010 segons les dades del Baròmetre de la comunicació i la cultura. Primeres estimacions", Estudis Romànics [Barcelona: Institut d'Estudis Catalans], vol. XXXIV, p. 347-365.

(ed). (2004) Calidoscopi lingüístic. Un debat entorn de les llengües de l'Estat, Barcelona, Octaedro.

REVISTA VALENCIANA DE FILOLOGIA / I (20I7) p. 223-239

MIQUEL ÀNGEL PRADILLA CARDONA

El model lingüístic educatiu a Catalunya el segle XXI / 238 
Pradilla, M. À.; Sorolla, N. (coord.) (2011a) Informe sobre la situació de la llengua catalana (2008-2009), Barcelona, Observatori de la Llengua Catalana. També disponible en línia a: <http://www.demolinguistica.cat/arxiu/web/informe/informe2008-09.pdf> [Consulta: 24 de setembre de 2017].

(2011b) Informe sobre la situació de la llengua catalana (2010), Barcelona, Observatori de la Llengua Catalana. També disponible en línia a: <http://www.demolinguistica.cat/arxiu/web/informe/informe2010.pdf> [Consulta: 24 de setembre de 2017].

(2012) Informe sobre la situació de la llengua catalana (2011), Barcelona, Observatori de la Llengua Catalana. També disponible en línia a: <http://www.demolinguistica. cat/arxiu/web/informe/informe2011.pdf> [Consulta: 24 de setembre de 2017].

-(2013) Informe sobre la situació de la llengua catalana (2012), Barcelona: Observatori de la Llengua Catalana. També disponible en línia a: <http://www.demolinguistica. cat/arxiu/web/informe/informe2012.pdf [Consulta: 24 de setembre de 2017].

-(2014) Informe sobre la situació de la llengua catalana (2013), Barcelona, Observatori de la Llengua Catalana. També disponible en línia a: <http://www.demolinguistica. cat/arxiu/web/informe/informe2013.pdf> [Consulta: 24 de setembre de 2017].

-(2015) Informe sobre la situació de la llengua catalana (2014), Barcelona, Observatori de la Llengua Catalana. També disponible en línia a: <http://www.demolinguistica. cat/arxiu/web/informe/informe2014.pdf> [Consulta: 24 de setembre de 2017].

Pradilla, M. À.; Torres, J. (2012) «Característiques demolingüístiques dels joves de Catalunya a finals de la primera dècada del segle XXI», Treballs de Sociolingüística Catalana [Barcelona: Institut d'Estudis Catalans], núm. 22, p. 119-134.

Sbert, M.; Vives, M. (1995) «El programa d'immersió a les Illes Balears», dins J. M. Artigal (ed.), Els programes d'immersió als territoris de llengua catalana, Barcelona, Fundació Jaume Bofill, p. 71-83.

Vila i Moreno, F. X. (2002) «Les politiques linguistiques dans les systèmes d'éducation des territoires de langue catalane», Terminogramme, núm. 103-104, p. 45-78.

- (2011). «La recerca sociolingüística educativa escolar als països de llengua catalana: elements per a un balanç», Treballs de Sociolingüistica Catalana [Barcelona: Institut d'Estudis Catalans], núm. 21: La sociolingüística catalana. Balanç i reptes de futur, p. 205-219. [Coordinat per M. À. Pradilla]

REVISTA VALENCIANA DE FILOLOGIA / I (20I7) p. 223-239

MIQUEL ÀNGEL PRADILLA CARDONA

El model lingüistic educatiu a Catalunya el segle XXI / 239 


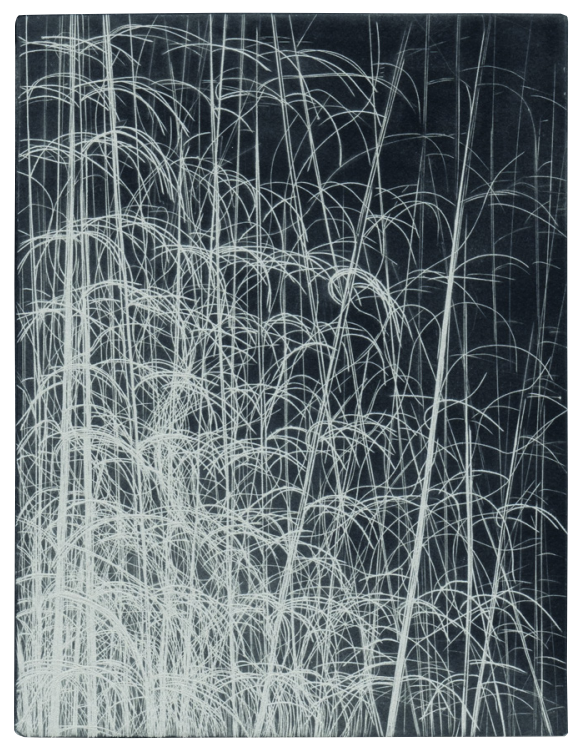

